\title{
LES MIGDIADES MUSICALS EN VALÈNCIA
}

\author{
Ramon RAMÍREZ I BENEYTO
}

\section{Resum}

En aquest article, l'autor fa públiques per primera vegada una sèrie de referències -recollides en la premsa, els llibres d'actes capitulars, protocols notarials i altres documents conservats a l'arxiu catedralici valencià- tocants a la celebració de migdiades de música, tant a la catedral metropolitana com en la resta d'esglésies i convents de la ciutat de València i els seus voltants. De tal manera que, amb això, es documenta perfectament la realització d'aquests concerts de música dintre del marc eclesiàstic valencià almenys des de principis del segle XVII fins ben entrat el segle XIX, demostrant-se igualment la pervivència en l'ús i el costum de realitzar aquest tipus d'actes musicals amb la intenció d'aconseguir un major lluïment en les festivitats que se celebren al llarg de tot aqueix temps. S'aporten també els llocs, les dates i les capelles que actuaven en cada moment, amb una possible aproximació al repertori interpretat.

\begin{abstract}
In this article, the author first makes public a series of references - from the press, church chapter's minute books, notarial deeds and other documents preserved at the Valencia Cathedral archives- which make reference to musical sessions held in the city cathedral and also in other church and convents in the city and surrounding areas. With this, it gets perfectly proved that these concerts were held in the frame of the Valencian church at least form the beginning of the $17^{\text {th }}$ century to some years into the $19^{\text {th }}$ century, at it also gets proved that the habit of helding this kind of musical sessions continued, with the aim of making the festivities held during all this time brighter. Also the places, dates and chapels where performances were held in each moment are offered, as well as a possible approximation to the repertoire played in them.
\end{abstract}

L'escarida definició que del terme "siesta" ens facilita Felipe Pedrell al seu diccionari (Pedrell, 1894: 418), és literal i idèntica de com ve arreplegada en una de les accepcions que per a aquesta paraula li adjudica el Diccionario de la Real Academia de la Lengua Española (AAVV, 1927: 1783) ${ }^{1}$. Cap dos no ens aporten moltes dades, es limiten a exposar que:

“siesta es (...) la música que en las iglesias se canta ó se toca por la tarde”.

Però és ben cert que aquestes migdiades musicals o concerts sacres eren actuacions orquestrals, simfònic-corals, d'orgue o bé de música de cambra, que es realitzaven a les principals catedrals espanyoles els dies de celebració més solemne, abans dels oficis de Vespres. No formaven part de les hores

1. També en (Moliner, 1991, II: 1162). 
canòniques ${ }^{2}$, ni de cap altre ritu litúrgic; més bé és tractava d'un tipus de manifestacions artístiques per solemnitzar d'una forma especial el dia de la festa de l'advocació a la qual estaven adscrits, bé el convent o l'Església Major, i aconseguir fer més atractiva la celebració per als fidels. Representen una mostra més de l'extrema prolongació en el País Valencià d'aquell sentiment barroc tan arrelat en les nostres terres ${ }^{3}$, en el qual es conceptuava la música religiosa com un espectacle. Així, desposseint-la de la seua severitat i gravetat tradicionals, s'acreixen els seus caràcters profans i es converteix de vegades, fins i tot, en mera diversió per a la feligresia.

El seu origen podríem trobar-lo en l'espècie de preludis instrumentals a les Vespres, que segons el professor Samuel Rubio es realitzaven en les principals catedrals espanyoles, al voltant del 2n quart del segle XVI, on:

“(...) después del repique de campanas, vuelven a oírse los ministriles y el órgano”.

(Rubio, 1983: 65).

Però les Migdiades, ja enteses com a tals concerts sacres, no han estat datades sinó a partir de principis del segle XVII, o bé com diu el professor López-Calo potser fins i tot a partir de finals del segle $\mathrm{XVI}^{4}$. En un principi només es realitzaven en la festa del Corpus Christi, però en la segona meitat del segle XVIII les veiem ací a València perfectament instal-lades també en altres festes majors, i fins i tot en festes menors.

Ha estat sovint publicada l'existència de nombroses notícies documentals que ens parlen de les solemnes sestes que es realitzaven a les catedrals i basíliques menors, tant a Castella i Andalusia com al Principat de Catalunya, durant els segles XVII i XVIII (López-Calo, 1.988; García Fraile, 1999); però no sabem que haja estat estudiat específicament el tema a València, almenys, en el període que ens ocupa. Més prompte al contrari, les poques referències que respecte d'això hem trobades a la bibliografia, pareix que s'obstinen en afermar que aquest fenomen hi havia passat de llarg i no s'havia arrelat al nostre país.

Però malgrat no tenir notícies de que haja estat estudiat aquest assumpte al País Valencià, basantnos en els avisos de celebració de cultes i festes religioses publicats a la premsa del moment, hem aconseguit referències suficients per poder afirmar que a finals del segle XVIII era una pràctica habitual, que mostra una tradició mantinguda i ben estesa, tant a les esglésies parroquials com als nombrosos convents que es repartien per la ciutat de València 5 , el fet de realitzar una "harmoniosa siesta" de música abans de les Maytines, les Vísperas o la Novena, "para más solemnizar la función”6, el dia de la celebració del patró titular, o per encàrrec d'algun noble o gremi, com acció de gràcies pels beneficis rebuts. És tracta d'una mostra més que reforça la realitat viscuda en aqueix moment: qualsevol motiu és bo per realçar la teatralitat que acompanya les funcions d'església d' aleshores.

2. Vide: Estructura de la liturgia hispánica y formas musicales, en (Fernández de la Cuesta, 1983: 121-145).

3. Com va demostrar Climent en algunes de les seues publicacions. Cfr. (Climent, 1977 i 1989).

4. Textualment "(...) perhaps even the end of the seventeenth century" (López-Calo, 1.983: xxxvi).

5. Sanchis Guarner ens relaciona 42 convents i catorze esglésies parroquials dintre del perímetre de les muralles de la ciutat, als que caldria afegir dues dotzenes de convents situats extramurs. (Sanchis Guarner, 1997: 316-318).

6. Diario de Valencia (LIII, 38: 154-155), del diumenge 4 de setembre de 1.803. 
Aquesta continuïtat en la celebració d'aquestos concerts sacres a valència -els trobem també fins ben entrat el segle XIX- en parèixer, també diferencia la pràctica i costums relacionats amb les migdiades musicals en el País Valencià, d'altres capitals espanyoles; on a partir de l'últim quart del segle XVII es van començar a prohibir aquestes "siestas musicales" per l'excessiu protagonisme que estaven prenent en detriment de la celebració del propi culte -al qual acompanyaven- i perquè els fidels arribaven a abarrotar els temples de tal forma, que es perdia totalment el decor i l'espiritualitat que es requerien pel lloc en què es celebraven ${ }^{7}$. Però sabem a més, que en la majoria d'ocasions, les migdiades, solien acompanyar la "reserva"; qüestió que suposava la presència en l'altar de les hòsties consagrades.

En el cas de la catedral de València en concret, també es pensava fins ara -i així ha estat publicat sovint tal informació- que mai no s'havien celebrades aquestes Migdiades, al menys dins del temple catedralici. Però nosaltres hem replantejat aquesta qüestió, a partir de la breu nota que trobarem en el diari de València, anunciant en 1.794 que:

"En la Santa Metropolitana Iglesia habrá siesta por la tarde a Santo Tomás de Villanueva."

(Diario de Valencia. XVII, 85: 334) ${ }^{8}$

Per l'escarit d'aquesta nota es desprèn que era una cosa prou habitual la celebració d'aquest tipus de concerts en la ciutat. Tant ho era, que no calia afegir més explicacions i era prou d'avisar que s'anava a produir l'esdeveniment. Els lectors del Diario de Valencia estaven tan acostumats a trobarse aquest tipus d'anuncis que resultaven del tot innecessàries majors explicacions. A més a més, la capacitat de convocatòria que la catedral exercia en la població i l'interés que despertaven les brillants actuacions de la seua capella de música, suposaven que el espectacle es prometia lluïdor.

Tot i què no se especifica la capella musical que intervenia, fàcilment podem deduir-hi que es tractava de la capella de música de la mateixa catedral, al front de la qual es trobaria el prevere D. Josep Pons com el seu mestre, perquè el capítol mai no hauria permès que una altra capella de música intervinguera a la Seu catedralícia. Aquest petit anunci de premsa ens suposà una dada molt important, perquè per primera vegada es trau a la llum, revelant-nos la pràctica habitual d'aqueixes Migdiades per la capella de la catedral. A més, en aquest cas que la migdiada estava dedicada a Sto. Tomás de Villanueva, era l'ocasió perfecta perquè s'escoltara entre les peces que s'interpretarien al concert l'impressionant himne a vuit veus d'aquest sant: "Pastorem canimus", el qual Josep Pons hi havia composat per la seua oposició al magisteri catedralici; fet que havia ocorregut no més un any abans.

7. Amb la publicació de les Actes del simposi internacional sobre l'òrgue històric celebrat a Salamanca, hem conegut noves i interessants dades relatives a la celebració, costums, horaris, obres que s'interpretaven, i la resta de qüestions relatives a les "siestas musicales" a Saragossa, Sevilla, Salamanca, Segòvia, Palència, i fins i tot en convents de religioses a Perú i altres països iberoamericans Cfr. (García Fraile, 1999). Podem afirmar sense cap dubte, que tant en aqueixos llocs com en els temples i convents de la ciutat de València, no eren altres que aconseguir captar un nombre més gran de fidels al temple per mitjà d'oferir-los, a més de la pròpia celebració religiosa -que ja suposava una festa plena de teatralitat-, l'atractiu d'escoltar una música (en ocasions totalment aliena al propi culte) l'objectiu últim de la qual no era un altre que el d'adornar encara més, tota aquella parafernàlia que havia d'enlluernar els sentits dels assistents.

8. Del dimarts 23 de setembre de 1.794 . 


\section{Les Migdiades i la capella de la catedral}

Aquest fet no ocorria llavors per primera vegada, doncs era una tradició llargament mantinguda i per descomptat romania ben arrelada, perquè havia estat practicant-se des de temps immemorial. Així havia estat almenys des de mitjans del segle XVII com podrem documentar. Hem arribat a aquesta conclusió gràcies a la troballa d'una breu referència a aquest assumpte, escorcollant a l'arxiu documental de la catedral valenciana, apareguda en les "cosas notables de Fuster" (ADCV, 4760: 1)9. Allí es fa referència a una deliberació capitular de l'any 1655 en la qual es va definir el que cada músic havia de cobrar per la seua participació en les migdiades.

“A 4 de Junio de 1655 deliberó [el capítol] que se saquen de la cuenta aparte Canonical veinte y una libras, que se paguen las Siestas de los siete días de la Octava del Corpus á los Músicos de ellas"10. (ADCV, ms 91: 298-299) $)^{11}$.

Vam buscar aqueixa deliberació capitular i vam trobar que coincidint amb les tesis del professor Samuel Rubio sobre les sestes per al Corpus que es celebraven en altres llocs d'Espanya ja esmentades, per primera vegada podíem documentar que també ací, en la catedral de València, venia éssent habitual la celebració de migdiades de música coincidint en les mateixes dates, doncs ací ocorria també per la mateixa festivitat del Corpus Christi. Però, a més a més, podem aportar també una petita precisió que ens sembla definitiva per aclarir aquest assumpte: no sols es realitzava el dia de la festa major com pensarem en un primer moment, sinó durant tots els dies de la vuitena que -com és tradició que es manté encara avui en dia- porta associada la celebració del Santíssim Corpus Christi. Diu textualment l'esmentada deliberació capitular del 4 de juny de 1655 de la qual dóna fe el notari Antonio Juan Tortrella:

"Unánimes et concordes et nemine discrepante providerunt et deliberarunt quod ap hinc inde perpetuis futuris temporis separentur apare canonicale viginti una libre monetae valentiae pro solbendis mucissis dictae Sanctae Eclesiae laboribus substinendis in septimis diebus octavae Corporis Domini nostri Iesu Christi ad rationem trium librarum pro quolibet siesta in quolibet ex dictis septem diebus fienda et celebranda"12.

(APCV, llig. 3128: 879v) ${ }^{13}$.

S'havia decidit per unanimitat del capítol que es pagaren les vint-i-una lliures de la Cuenta Aparte Canonical per a cobrir les despeses dels músics que participaven a les migdiades de cadascun dels set dies que completaven la vuitena i que així quedara establert perpètuament. També sabem que aquest costum es va mantenir almenys fins a l'any 1849, en el que Vicente Boix ens presenta aquest ús en el seu manual per a viatgers, com quelcom habitual en totes les esglésies de la ciutat:

9. Manuscrits arreplegats pel Dr. Melchor Mauricio Fuster, Canonge Magistral i Paborde de la catedral de València.

10. El subratllat és nostre.

11. Arxiu Documental. Catedral de València.

12. El subratllat és nostre.

13. Actes de Protocols. Catedral de València. 
"Los días de la octava están consagrados á las procesiones de las demás parroquias. Compiten todas en lujo, en adornos de calles y en músicas".

(Boix, 1849: 242).

D'una altra banda, també sabem que la realització d'aquestes sestes no era un fet que se circumscriguera només a la ciutat de València. Per llavors també es feien en altres localitats, com ho testifica el document que Josep A. Lluesma i Espanya va donar a conèixer en el seu estudi sobre la parroquial de Santa Maria de Sagunt. Allí apareixen reflectits -en una època molt primerenca- els pagaments realitzats pel clavari de la confraria del Santíssim Sagrament d'aquella església saguntina -que per a aquell any havia sigut D. Jeroni Barta- al mestre de capella i a dos cantors més per cantar i tocar l'orgue en la migdiada celebrada el dia principal de la festa d'aquell any de 1650. Tanmateix aquest autor ens suggereix que tot açò delata una pràctica absolutament habitual en les cerimònies litúrgiques d'aquella ciutat:

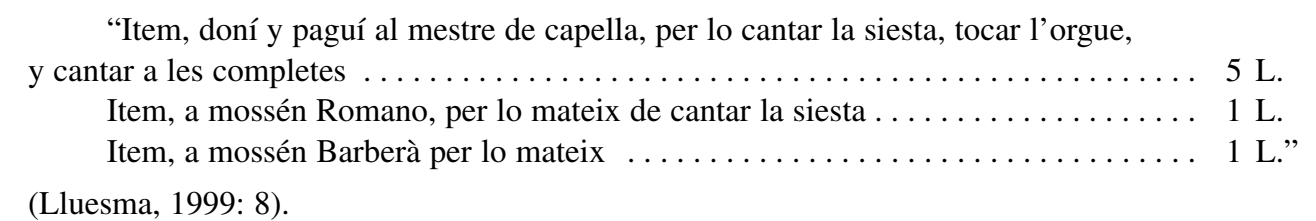

De la continuïtat mantenida al llarg del temps que aquestes sestes musicals van tenir, podem fernos una idea perquè n'hi ha referències periòdiques a elles, tant als llibres d'actes capitulars com d'altres documents de l'arxiu de la catedral. Per exemple, sabem com va ocórrer els dies 1, 4 i 6 de maig de 1661 quan s'organitzaren les habituals rogatives i es feren processons generals per a demanar la pluja que estava éssent tan necessària per la sequera que estava patint-se al País. Per a allò es varen unir totes les forces vives de la capital, i es comptava amb la participació de tots els estaments ciutadans i no sols dels religiosos. Així, van assistir-hi l'arquebisbe, el capítol, els convents, les parròquies i tot el clero general de la ciutat, portant les relíquies de Sant Vicent Ferrer en processó de rogatives, fins arribar-hi al convent de Sant Domènech el dia 1; i també -com s'acostumava- és va comptar amb la participació del virrei, el governador, el batlle, la ciutat i tots els oficials reials que romanien a València. Va estar exposat el Santíssim en la catedral -els tres dies que es marquen segons costum-, i van ésser els dies 4, 5 i 6. La Mare de Déu dels Desemparats també va estar exposada en la seua capella. Els tres dies va haver-hi migdiada a la catedral com ens relata detalladament el canonge Fuster:

"Processó general de sent Vicent a Sent Domingo, per aigua. A 1 de maig, 1661, se féu processó general a Sent Domingo, per aigua, ab tots los convents y parròquies, portant la custòdia y relíquia de sent Vicent. Y assistí el senyor arquebisbe, virrey, ciutat, governador, bal·le y demés officials reals.

Nostre Senyor patent, nostra Senyora y sent Vicent, per aigua. A 4 de dits estigué nostre Senyor patent en la Seu, y nostra Senyora dels Desemparats y la relíquia de sent Vicent Ferrer, per pregàries de aigua. Y estigué tres dies en esta conformitat.

Tanquen a nostre Senyor y tornen a nostra Senyora y a sent Vicent a ses capelles. A 6 de dits tornaren, després de haver tancat a nostre Senyor, a nostra Senyora y a sent Vicent a ses capelles. Y tots 
los tres dies agué siesta y una ora de oració mental en lo chor, y el senyor arquebisbe, después que era de nit, baixava en tota sa família y dien lo rosari a chors."

(ADCV, ms 91: 298-299) ${ }^{14}$.

La convocatòria va ser tan general que a partir del dia següent, 7 de maig, totes les esglésies de la ciutat per orde de jerarquia van continuar amb els actes d'exposició del santíssim, música i sermó que havia iniciat la catedral com a església matriu. Així es van realitzar sestes musicals per tot arreu de la ciutat:

"Nostre Senyor patent en totes les parròquies per aigua. A 7 de dits comensaren totes les parròquies per son orde, a tenir un dia cada una, patent, a nostre Senyor, ab música y sermó cada día."

(ADCV, ms 92: 9) ${ }^{15}$.

En parèixer -si atenem el resultat aconseguit- els cels van ser complaents, perquè com explica el mateix canonge Melchor Fuster va estant plovent tres dies i tres nits sense parar:

"Plou en València tres dies y tres nits, sens parar. Dit dia fonch nostre Senyor servir de oir les oracions de tantes ànimes bones en tan gran aflicció y apreto en la falta de aigua, pués comensà a ploure y plogué tres dies en ses nits, sens parar, que foren 8,9 y a $10 . "$

(ADCV, ms 92: 9).

Les celebracions litúrgiques de agraïment i l'alegria que portava l'aigua rebuda es van multiplicar, i així veiem que el dia 19 del mateix mes, en la catedral, després de celebrada la missa i cantat el solemne Te Deum d'acció de gràcies, quan ja s'havien retirat el senyor arquebisbe que vestia de pontifical, el virrei, la il-lustre ciutat i la representació de totes les parròquies que també van assistir a la cerimònia, i després de l'hora d'oració a migdia que van tenir els senyors canonges i els beneficiats de la catedral, es va realitzar una hora de sesta abans de les vespres segons costum:

"A 19 de dits, per donar a nostre Senyor les degudes gràcies per la mercé que ens féu de donar-nos aigua en necessitat tan apretada -pues ya les plantes, així com de albres com de vinyes, molt a presa se anaven secant-, en la iglésia machor descubriren a nostre Senyor, tenint-lo patent (...).

A migdia agué vel·la, en lo altar machor, de canonches y beneficiats, però no estigueren achenollats com en la ocació pasada, perquè entonces eren plegàries y ara eren gràcies. A les dos ores agué sies$t a^{16}$ y a les tres se digueren les vespres, les quals foren del dia, ab molta pausa però sinse música..."

(ADCV, ms 91: 299; ms 92:9v).

Com també ocorria en un altre tipus de celebracions, ja que a l'agost de 1663 la confraria de la Mare de Déu dels Desemparats -de la qual era prior el mateix senyor canonge D. Melcior Fuster-

14. Citat a més en (Aierdi, 1999: 173).

15. Ibíd.

16. El subratllat és nostre. 
éssent majordoms de la festa D. Balhasar de Borja i D. Raymundo Polop, van celebrar amb molt de luxe i gran dispendi de mitjos tots els dies de la vuitena que també se li va afegir. Arribant a córrer els mateixos senyors amb les despeses de les sestes que -al llarg de totes les vesprades dels set dies- va estar realitzant la capella de música de la catedral i com imaginàvem, tots els actes contaren amb una important assistència de públic, com també posava de relleu en el seu relat el canonge fuster:

“(...) después de haver los beneficiats de la Seu cantat ab molta devoció un[a] salve, es cantà una siesta per la copla dels músichs de la Seu${ }^{17}$. Agué, així de matí com de vesprada moltíssim concurs de chent."

(Aierdi, op. cit.: 318 ).

També més avant, en 1728, éssent José Pradas el mestre de la capella, quan es torna a insistir en les normes dictades anteriorment -doncs ja ho havia estat el 9 de maig de 1626 i el 17 d'agost de 1714per al bon govern de la capella de música, ja que en parèixer s'havien produït alguns abusos per part dels músics relacionats amb les quantitats que es pretenien cobrar en les eixides de la capella per actuar fora de la catedral. En aquestes normes queda específicament determinada la quantitat exacta que s'ha de cobrar en funció de si la capella acudeix completa o només una part d'ella i del tipus d'actuació que és va a realitzar. És a dir, si es tracta d'una Missa, Vespres, Completes, Siesta de Villancicos”, o bé si en l'església on s'actua hi ha orgue o pel contrari cal transportar-lo. Queda clarament exposat tot el referent a aquestes actuacions, delimitant exactament quant correspon a cada tipus d'actuació. Per elles sabem també de la continuïtat que van tenir les migdiades de música realitzades per la capella de la catedral a la resta de la ciutat i les rodalies. Vegem-la novament:

"Deliberació Capitular 15 de Desembre de 1.728.

(...) Primerament: Que no podent, com no poden subsistir en la decencia deguda, les mitjes Capelles, que se han tolerat fins lo dia de hui, menys que ab gran desdoro del cor de la Capella, es revoca esta practica, y pera de hui en avant determinem, que no es puixa admetre funció alguna menys que de Capella sansera, exceptant els Misereres, els actes de Capella de la de Nostra Señora del Milacre, y de la de Nostra Señora dels Desamparats, en los quals es podra dividir la Capella com se ha fet fins hui en la forma que se ordená en dit any mil setcents catorce.

Item; Que no es puixa rebaixar cosa alguna de la tasa que baix se espresara, que ha de servir de regla en tots els actes de Capella, exceptant les funcions amortizades, y de temps in memorial, con son la música del dia de Sant Ambros en Sant Nicolau, y la del dia de la mare de Deu de la Esperanza en Sant Martí, y altres semejants, en les quals deu asistir la Capella per lo estipendi, que ab antiquo se li ha donat; y que dita tasa dia en esta forma: en los actes de Misses, Vespres, Completes y Siesta de Villancicos en la Esglesia que hiaura Orgue, en cascun acte es donará pera la Capella set Liures y huit Sous y pera el organiste, dotze sous y si el orgue se ha de portechar es convindrá el organiste en la part; Y en les Misses ab Te Deum se añadiran tres Liures mes: en los actes de processons claustrals en qualsevol Esglesia, o, per lo rededor de ella, es donarán set Liuresy huit Sous pero si se alluñaran notablement de la Esglesia, huit Liures y huit Sous; En los actes de Maytines y de Te Deum Laudamus, si hia Orgue en la Esglesia hon fan lo acte es pagará pera la Capella huit Liures, y huit Sous, y dotze Sous pera el Organiste; En les soterrars de una tanda en Missa de Requiem, huit Liures: si es Missa blanca, ó, del dia, com també

17. El subratllat és nostre. 


\begin{abstract}
Vespres, nou Liures; en soterrar sens Missa, ni Vespres sis Liures y en los de dos, o, mes tandes, les dos primeres es paguen per sancer, y en les demes el Mestre, ab los quatre Músics sacerdots mes antics faran la conveniencia, que el pareixerá; de un Miserere ab tota la Capella sis Liures; En les funeraries de una Missa ab respons, á dotze, es donarán deu Liures, en una acció de gracies tant solament de Te Deum Laudamus sis Liures; y en funció de letanies, nou Liures.

Item; Que tots els actes acompañats de violins, á mes de la Liura mes, y si es fora de Valencia, dos Liures, de forma que sien tres Liures en tot, per lo gran exces y diferencia del treball.

Item; Que quant la Capella está empleada en alguna funció y al mateix temps es canta alguna Siesta, Rosari o Motet, encara que solament estiga comensat qualsevol de dits actes durants lo acte de Capella, hatja de entrar en la masa comuna de la Capella, les porcions que aquells que faltaran a la Capella guañaran.

Item; Que es nomene un concertador, que juntament sia apuntador y contador, y que no puixa ser dels que canten Siestes ni Rosaris, ab lo Salari de huit sous cascun més, conforme es practicaba antigament donar per salari de contador..."18
\end{abstract}

(APCV, llig 3212: 1458-1461v).

Com veiem el tema de les migdiades apareix tractat també en 1728 amb tota naturalitat, com el que era, una cosa absolutament quotidiana. I així continua éssent durant tot el segle i són nombroses les referències que és troben reflectides per tot arreu dels llibres de registres:

“(...) Siestas se convoque á Msn. Mariano Terranegra en 1 de Julio 1788.”

(ADCV, 1631: 78) ${ }^{19}$.

“(...) Oído el informe dado por el Señor Canónigo D. Luis Lasala al Memorial de Felipe Aranda, el Ilmo. Cabildo acordó, buelva al mismo Señor Lasala, y al Señor Canónigo Síndico para que oyendo al Maestro de Capilla y sobre los demás puntos en orden á las datas que disfrutan los Músicos en las Siestas y demás funciones dispongan las reglas que deben gobernarles en lo succesivo, y dejen á arbitrio del Maestro de Capilla el señalamiento de los Instrumentos, y Músicos que deben tocar en ellas"20.

(ACCV, 338: 103) ${ }^{21}$.

\title{
Les migdiades musicals a la ciutat de València en el canvi de segle (1794-1818)
}

Però no era només la capella de la catedral l'encarregada de realitzar les sestes musicals a València. Potser quan el pressupost era més limitat i no es podia assumir el cost de la principal capella de música de la ciutat, o bé la capella de la catedral estava ocupada en altres assumptes i no podia acudir-hi, es recorria doncs a una altra de les nombroses capelles de música que -amb uns mitjans més modestos és cert- també exercien la seua labor des de les parròquies de Sant Andreu, Sant Martí, Sant Joan del Mercat, etc... Totes aquestes capelles parroquials estan reflectides en els avisos de culte apareguts a la premsa del moment, realitzant sestes de música allí on se celebra la festa de la devoció d'una

18. Els subratllats són nostres.

19. ADCV "Libro de Salarios y nombramientos de los capellanes cantores...".

20. Els subratllats són nostres.

21. Actes Capitulars. Catedral de València. 
confraria, un gremi o un barri determinat. Si a més, tenim en compte la possibilitat que no totes les sestes que es van celebrar estigueren anunciades en la premsa, per un o un altre motiu, ens trobaríem -segurament- amb un important entramat de concerts sacres repartits per tota la ciutat i en totes les èpoques de l'any.

Escorcollant les publicacions periòdiques d'aqueixos anys hem trobat les ressenyes d'un total de 52 migdiades celebrades a les diferents esglésies de la ciutat de València des de l'any 1794 fins 1818, marc que s'imposarem com a franja en la qual treballar estos aspectes. Amb estes noves aportacions que fem de les actuacions de les capelles a les migdiades per tot arreu de la ciutat, canvia notablement el plantejament i la imatge que fins ara podem trobar-hi a la bibliografia que tracta la referida activitat musical valenciana d'aqueix moment històric.

Aquestes dades les hem obtingudes de l'única publicació periòdica valenciana que es manté a la venda durant tot aquest espai de temps: el Diario de Valencia. Malauradament, de totes les migdiades que hem pogut documentar, podem comprovar que sols en 21 es fa referència a la capella de música que actuava; en 31 només apareix una orquesta de música. Atorgant-li, aixó sí, qualificatius tan expressius com: acorde música, harmoniosa siesta de música, devota siesta de música, plausible música, lucidíssima música, o senzillament només es diu: habrá siesta.

En una ocasió que era de gran rellevància -la funció va haver de ser realment sumptuosa- celebrada amb motiu de la inauguració del nou Retaule de l'Altar Major i les obres de reforma del Presbiteri i Cor, de l'Església Parroquial del proto-màrtir Sant Esteve -una de les més importants parròquies de València i molt unida a la catedral- ve ressenyat de la següent manera:

"acompañando dicha función el mejor concierto de instrumentos músicos"

(Diario de Valencia, L, 83: 375-376) ${ }^{22}$.

Podem comprovar com el periodista, sense cap tipus de rubor, denomina l'actuació com "concierto". Açò suposa una tímida mostra més, de la relativa permeabilitat dels termes laics, que a poc a poc, es van adoptant malgrat els esforços fets pels rígids estaments catedralicis en no deixar que ocorrira i per poder-hi continuar gaudint d'aquell privilegi social que mantenia, el qual havia estat tant assumit al llarg de tants segles. No hi ha dubte que aquest dia va ser important. Perquè per a aquesta celebració, la Capella de Música de la catedral amb el seu mestre Josep Pons al front, va mostrar les seues millors gales. Triant per a l'ocasió el Te Deum composat pel mateix mestre de la capella Josep Pons, per a l'actuació que va tenir lloc a la catedral, amb motiu de la visita de "SS.MM. y AA. a esta Ciudad" l'any 1802 i en la qual participaren més de 60 músics ${ }^{23}$.

Pel que fa al repertori que s'interpretava només en 6 ocasions ve especificat que es cantaren els villancets de la Nit de Nadal, o bé que s'inclourien, a més dels villancets, les lletanies. En una d'elles es fa referència a "dos coros de música", que ens podria portar a deduir la participació també de veus humanes -solistes o cor- amb aquell plantejament policoral típic de les capelles valencianes, o bé faria

22. Del dimecres 1 de desembre de 1.802 .

23. Cfr. (Diario de Valencia, L, 77: 349 ss) del dijous 16 de desembre de 1.802 on es publica una detallada descripció dels actes i cerimònies que es van celebrar amb motiu de la permanència en la ciutat de SM Cales IV i tota la seua cort. 
referència al cor vocal i el cor instrumental en aquests concerts sacres. Però és evident, que la pràctica habitual venia sent que actuaren veus i instruments, encara que com hem vist, la decisió de quines veus i quins instruments devien participar-hi en cada actuació ben bé era assumpte que concernia al propi mestre, perquè el violins sempre hi anaven:

"Que en cuanto a los Rosarios, y Siestas, ò, cosa semejante, hayan de ir unos una vez, y otros otra a dirección del Maestro respeto de las voces, por que los violines es preciso que vayan" 24 .

Exceptuant fins i tot els pocs casos en què només es diu que hi haurà una "siesta de música" sense especificar quins instruments hi participen, suposant que no més actuara l'orgue, és evident que a la majoria de les sestes, a més de la música vocal, se completava el programa amb l'interpretació de gran part del repertori amb música purament orquestral.

En quant a la duració que podia suposar qualsevol d'aquestes actuacions, comprovem que tampoc no hi havia un criteri uniforme, variant molt d'un lloc a l'altre i d'una festa a l'altra. Així podem veure que de vegades la duració podia estar al voltant d'una hora:

"por la tarde habrá una hora de siesta, á que seguirá la Novena"25.

Una hora i mitja:

"desde las 5 hasta dicha hora [ 7 de la vesprada ] habrá siesta con orquesta de música"26.

I fins i tot arribar a les tres hores de duració, com va ocórrer el 5 d'abril de 1798, quan a més hi havia en dos llocs a la mateixa vegada:

"Esta noche en la Iglesia Parroquial de Santa Cruz y en la del Convento de Capuchinos, habrá siesta de música, desde las 7 hasta las 10 de la misma"27.

Aquestes duracions que avui poden parèixer exagerades, no ens resulten gaire estrany ja que possiblement gran part de les celebracions litúrgiques del moment estarien a prop de durar el mateix, vist l'important aparell de pompositat que les acompanya i eixa certa "teatralitat didàctica" típicament barroca que les presideix com ho mostren les descripcions -perfectament detallades per un altre costat- que trobem als documents capitulars als quals hem tingut accés al llarg de la nostra investigació.

Per tant, podem parlar de grans concerts que es celebraven a les esglésies, on els protagonistes eren les capelles musicals i els oïdors els feligresos, pertanyents a totes les capes socials. No obstant,

24. "Capítol 25 dels Estatuts fundacionals de la capella de música del Palau Reial”. Citat en Pingarrón (1.983: 14).

25. Diario de Valencia (XLIV, 73: 325) del divendres 12 de juny de 1.801.

26. Ibíd. (XX, 140: 197) del dimecres 20 de maig de 1.795.

27. Ibíd. (XXXII, 94: 383) del dijous 5 d'Abril de 1.798. 
els cavallers i les senyores estaven situats en un cadafal a propòsit, i açò és una mostra més de l'evident separació de categories socials que regia la vida diària d'aquella societat immersa llavors, a principis del segle XIX, en aqueixa dinàmica de privació dels principis d'equitat -qüestió que estava gestant-se llavors- símptoma notori del poc que s'havia avançat en la consecució dels drets humans arran el nostre país:

“(...) los senyores acudiren a l'estrado ab molt lloïment..."28

La grandesa del temple, la majestuositat del cor, amb les seues cadires replenes del clero, la riquesa del retaule, la fastuositat dels ornaments sagrats, el nombre dels oficiants -potser presidits pel bisbe aposentat al seu setial- i la nau abarrotada de fidels, constituïen sense cap dubte un espectacle enlluernent, que exigia el complement d'una música agradable, composta d'acord amb el gust dels oïdors als quals anava dirigida:

“(...) y de 5 a 6 de la tarde habrá una agradable siesta..."29

A la vista de totes aquestes dades, vàrem llançar la nostra hipòtesi de que les obertures i simfonies de Josep Pons ${ }^{30}$, les quals van ser composades per a ser interpretades en els ofertoris $\mathrm{i}$ altres moments de la missa en els quals com diu el costum, venia realitzant-se des de prou temps arrere, però -i això és el més important- també formarien part del repertori d'obres que s'interpretaven en les nombroses sestes musicals que com hem vist va realitzar la capella de música de la catedral valenciana, als anys en què Josep Pons va estar al front de la mateixa. Perquè donat el prestigi social i econòmic que venia associat al càrrec de mestre de capella a la catedral, entenem que cap desestimar la possibilitat que dites obres exclusivament orquestrals estigueren composades per servir altres fins que els propis de la interpretació dins del temple. Josep Pons no necessitava rebaixar-se de la dignitat del seu càrrec, per a formar part d'aqueix grup de músics que tocaven als teatres ni a les acadèmies; a més, ja ha estat comentat que el capítol catedralici ho tenia rigorosament prohibit. Per un altre costat, com ja veurem, la seua pròpia condició de prevere el va induir a compondre durant tota la seua vida, de manera fonamental, música per al culte.

Al següent quadre hem fet coincidir la data i lloc de celebració de cada migdiada, a més de fer referència a la capella que intervenia. A pesar que no hem trobat dades dels anys 1.800, 1.809, 1.812, 1.813 i 1.814; creguem que la inserció d'aquestos anys pot aclarir i ajudar a comprendre la rellevància que van tenir i el tracte que hem d'atorgar-los, donat el gran nombre de sestes musicals que es van realitzar a la ciutat de València.

28. Aierdi, op. cit.: 318.

29. Diario de Valencia (CXIII, 63: 186) del divendres 3 de juliol de 1.818.

30. Les quals es conserven a l'arxiu de música catedralici i nosaltres donàrem a conèixer a partir dels originals que allí romanen. Cfr.: (Ramírez, 1999). 


\begin{tabular}{|c|c|c|c|}
\hline \multicolumn{4}{|c|}{ Migdiades Musicals a València } \\
\hline Any & Data & Lloc de celebració & Actuant \\
\hline 1794 & $\begin{array}{l}25 \text { de Juliol } \\
23 \text { de Setembre } \\
18 \text { de Desembre }\end{array}$ & $\begin{array}{l}\text { Convento de Santa Úrsola } \\
\text { Santa Iglesia Metropolitana } \\
\text { San Martín }\end{array}$ & $\begin{array}{l}\text { No consta } \\
\text { No consta } \\
\text { No consta }\end{array}$ \\
\hline 1795 & $\begin{array}{l}20 \text { de Maig } \\
18 \text { de Desembre }\end{array}$ & $\begin{array}{l}\text { San Antonio Abad } \\
\text { San Martín }\end{array}$ & $\begin{array}{l}\text { Capilla de la Catedral } \\
\text { No consta }\end{array}$ \\
\hline 1796 & $\begin{array}{l}10 \text { de Maig } \\
30 \text { de Setembre } \\
18 \text { de Desembre }\end{array}$ & $\begin{array}{l}\text { Convento de Santa Úrsula } \\
\text { Convento de San Agustín } \\
\text { San Martín }\end{array}$ & $\begin{array}{l}\text { Capilla de los Santos Juanes } \\
\text { Capilla de la Catedral } \\
\text { Capilla de la Catedral }\end{array}$ \\
\hline 1797 & $\begin{array}{l}17 \text { de Maig } \\
2 \text { de Juliol }\end{array}$ & $\begin{array}{l}\text { San Antonio Abad } \\
\text { Santa Catalina }\end{array}$ & $\begin{array}{l}\text { No consta } \\
\text { No consta }\end{array}$ \\
\hline 1798 & $\begin{array}{l}5 \text { de Abril } \\
5 \text { de Abril }\end{array}$ & $\begin{array}{l}\text { Santa Cruz } \\
\text { Convento de Capuchinos }\end{array}$ & $\begin{array}{l}\text { No consta } \\
\text { No consta }\end{array}$ \\
\hline 1799 & 25 de Febrer & San Bartolomé & Capilla de los Santos Juanes \\
\hline 1801 & $\begin{array}{l}12 \text { de Juny } \\
7 \text { de Agost } \\
13 \text { de Agost } \\
14 \text { de Agost } \\
15 \text { de Agost }\end{array}$ & $\begin{array}{l}\text { Convento de Santa Úrsula } \\
\text { Santa María Magdalena } \\
\text { Capilla de la Virgen Desamparados } \\
\text { Capilla de la Virgen Desamparados } \\
\text { Capilla de la Virgen Desamparados }\end{array}$ & $\begin{array}{l}\text { No consta } \\
\text { Capilla de la Catedral } \\
\text { No consta } \\
\text { No consta } \\
\text { No consta }\end{array}$ \\
\hline 1802 & 24 de Gener & Convento de Santa Úrsula & Capilla de los Santos Juanes \\
\hline 1803 & $\begin{array}{l}19 \text { de Març } \\
28 \text { de Maig } \\
22 \text { de Juliol } \\
28 \text { de Juliol } \\
7 \text { de Agost }\end{array}$ & $\begin{array}{l}\text { Nuestra de Señora del Carmen } \\
\text { Convento de Capuchinos } \\
\text { Santa María Magdalena } \\
\text { Convento de San Cristóbal } \\
\text { Santa María Magdalena }\end{array}$ & $\begin{array}{l}\text { Capilla de la Catedral } \\
\text { Capilla de San Martín } \\
\text { Capilla de la Catedral } \\
\text { No consta } \\
\text { Capilla de la Catedral }\end{array}$ \\
\hline 1804 & $\begin{array}{l}18 \text { de Gener } \\
22 \text { de Març } \\
19 \text { de Juliol } \\
7 \text { de Agost }\end{array}$ & $\begin{array}{l}\text { Convento de San Francisco } \\
\text { Santa María Magdalena } \\
\text { Convento de Santa Úrsula } \\
\text { Santa María Magdalena }\end{array}$ & $\begin{array}{l}\text { No consta } \\
\text { Capilla de la Catedral } \\
\text { Capilla de los Santos Juanes } \\
\text { Capilla de la Catedral }\end{array}$ \\
\hline 1805 & $\begin{array}{l}20 \text { de Gener } \\
29 \text { de Juliol }\end{array}$ & $\begin{array}{l}\text { San Sebastián } \\
\text { Convento de Santa Úrsula }\end{array}$ & $\begin{array}{l}\text { No consta } \\
\text { No consta }\end{array}$ \\
\hline 1806 & $\begin{array}{l}14 \text { de Juliol } \\
7 \text { de Agost } \\
15 \text { de Agost } \\
5 \text { de Octubre }\end{array}$ & $\begin{array}{l}\text { Convento de San Francisco } \\
\text { Santa María Magdalena } \\
\text { San Felipe Neri } \\
\text { San Josef }\end{array}$ & $\begin{array}{l}\text { No consta } \\
\text { Capilla de la Catedral } \\
\text { No consta } \\
\text { No consta }\end{array}$ \\
\hline
\end{tabular}




\begin{tabular}{|c|l|l|l|}
\hline Any & Data & Lloc de celebració & Actuant \\
\hline 1807 & $\begin{array}{l}25 \text { de Gener } \\
\text { de Agost } \\
15 \text { de Agost } \\
21 \text { de Octubre }\end{array}$ & $\begin{array}{l}\text { Convento de San Francisco } \\
\text { Santa María Magdalena } \\
\text { San Felipe Neri } \\
\text { Convento de Santa Úrsula }\end{array}$ & $\begin{array}{l}\text { No consta } \\
\text { Capilla de la Catedral } \\
\text { No consta } \\
\text { No consta }\end{array}$ \\
\hline 1808 & $\begin{array}{l}6 \text { de Gener } \\
12 \text { de Octubre } \\
1810\end{array}$ & $\begin{array}{l}\text { San Vicente de la Roqueta } \\
\text { Convento de Santa Úrsula } \\
\text { Convento de San Cristóbal } \\
\text { Convento de Santa Úrsula }\end{array}$ & $\begin{array}{l}\text { Capilla de San Martín } \\
\text { No consta } \\
\text { Capilla de la Catedral } \\
\text { No consta }\end{array}$ \\
\hline 1811 & 13 de Novembre & Seminario Sacerdotal & No consta \\
\hline 1815 & 29 de Juliol & Convento de Santa Úrsula & No consta \\
\hline 1816 & $\begin{array}{l}20 \text { de Octubre } \\
24 \text { de Novembre }\end{array}$ & $\begin{array}{l}\text { Convento de Santa Úrsula } \\
\text { Convento Nta. Sra. Presentación }\end{array}$ & $\begin{array}{l}\text { No consta } \\
\text { Capilla de la Catedral }\end{array}$ \\
\hline 1817 & $\begin{array}{l}30 \text { de Abril } \\
15 \text { de Octubre }\end{array}$ & $\begin{array}{l}\text { Iglesia del Real Hospital General } \\
\text { Convento de Santa Úrsula } \\
\text { Convento de San Juan de Ribera }\end{array}$ & $\begin{array}{l}\text { No consta } \\
\text { No consta } \\
\text { No consta }\end{array}$ \\
\hline 1818 & $\begin{array}{l}3 \text { de Juliol } \\
21 \text { de Novembre }\end{array}$ & $\begin{array}{l}\text { Convento de Santa Úrsula } \\
\text { Convento de la Corona } \\
\text { Convento de San Agustín }\end{array}$ & $\begin{array}{l}\text { No consta } \\
\text { Capilla de la Catedral } \\
\text { Capilla de la Catedral }\end{array}$ \\
\hline
\end{tabular}

\section{Bibliografía}

AIERDI, Joaquim (1999): Dietari. Notícies de València i son Regne de 1661 a 1664 i de 1667 a 1679. A cura de Vicent Joseph Escartí. Barcelona: Editorial Barcino.

Borx, Vicente (1849): Manual del viajero y guía de los forasteros en Valencia. València: Imprenta de José Rius. [Reproducció facsímil] València: Librerías París Valencia].

FERNÁNDEZ DE LA CuESTA, Ismael (1983): Historia de la música española I. Desde los orígenes hasta el Ars Nova. Madrid: Alianza Música.

FUSTER, Melchor: Deliberaciones modernas y notables y cosas dignas de advertencia del muy ilustre cabildo de la santa Iglesia de Valencia. Manuscrits arreplegats pel Dr. Melchor Mauricio Fuster, Canonge Magistral i Paborde de la catedral de València. (ADCV ms 90 a 93).

García Fraile, Dámaso (1999): Órgano hispánico y fiesta barroca. En Actas del simposio internacional "El órgano hispánico en Castilla y León" (Salamanca, 1996). Zamora: Junta de Castilla y León. Consejería de Educación y Cultura.

Lluesma, Josep A. (1999): Los órganos de Santa María de Sagunto y el mundo musical de su entorno. En Cabanilles, 31 de gener-març. València.

López Calo, José (1.983): La música en la Catedral de Santiago. Vol. IV. Catálogo del archivo de música. La Coruña: Exma. Diputación Provincial. 
- (1988): Historia de la música española III. Siglo XVII. Madrid: Alianza Música.

Moliner, María (1991): Diccionario de la Lengua Española. II vol. Madrid: Gredos.

PeDRell, Felipe (1984): Diccionario técnico de la música. Barcelona: Isidro Torres Oriol. [Reproducció facsimil] València: Librerías París Valencia.

PingarRón (1983): La música en la parroquia de San Martín de Valencia (SS. XVI-XX). En Cabanilles, 1-2 de genermarç. València.

RAmíReZ Beneyto, RAmón (1999): Aproximació al llenguatge instrumental de Josep Pons: Simfonies i obertures per a orquestra a l'arxiu de música de la catedral metropolitana de València. Treball d'investigació llegit al Department de Teoria dels Llenguatges de la Facultat de Filologia de la Universitat de València. Mecanografiat.

Rubio, Samuel (1983): Historia de la música española II. Desde el Ars Nova hasta 1600. Madrid: Alianza Música.

SAnchís GuARner, Manuel (1.972): La ciutat de València. Síntesi d'història i de geografia urbana. València: Generalitat Valenciana / Universitat de València / Exm. Ajuntament.

AAVV. (1927): Diccionario Manual e ilustrado de la Lengua Española. Madrid: Espasa Calpe. 